\title{
Impact of economic factors on life insurance development in Western Balkan Countries*
}

\author{
Milijana Novović Burićn , Julija Cerović Smolović2, \\ Milena Lipovina Božović ${ }^{3}$, Ana Lalević Filipović ${ }^{4}$
}

\begin{abstract}
Life insurance market in Western Balkan countries is underdeveloped compared to other European countries, but in the recent decade it has been developing moderately under the influence of various factors, primarily economic, but also demographic, political and other. The aim of this manuscript is to analyze and indicate the most significant economic factors that have important influence on life insurance products purchase. In order to prove the hypothesis established in the manuscript, panel data analysis is used to examine the impact of GDP, unemployment rate, wages and interest rate on total life premium in Western Balkans in the period 2005 to 2015. The results of the analysis showed that the above-mentioned economic factors mainly affect total life premium in countries of the Western Balkans. GDP and wages have a significant and positive impact on demand for life insurance, while the impact of unemployment rate and interest rate is negative.
\end{abstract}

Key words: life insurance market, economic factors, insurance premium, panel data model, the Western Balkans

JEL classification: G22, C23, O52,O11

\footnotetext{
* Received: 4-03-2017; accepted: 21-12-2017

1 Assistant Professor, University of Montenegro, Faculty of Economics, Jovana Tomaševića 37, 81000 Podgorica. Scientific affiliation: finance, insurance, accounting. Phone: +382 20241 138.Fax:+382 20244 588.E-mail:mnovovic@ac.me.

2 Teaching assistant, University of Montenegro, Faculty of Economics, Jovana Tomaševića 37, 81000 Podgorica. Scientific affiliation: finance, statistics, mathematics. Phone: +382 20241 138. Fax: +38220244 588.E-mail: julija@ac.me.

3 Teaching assistant, University of Montenegro, Faculty of Economics, Jovana Tomaševića 37, 81000 Podgorica. Scientific affiliation: macroeconomics, statistics, mathematics. Phone: +382 20241 138.Fax: +38220244 588.E-mail:mlipovina.bozovic@googlemail.com.

4 Associate professor, University of Montenegro, Faculty of Economics, Jovana Tomaševića 37, 81000 Podgorica. Scientific affiliation: accounting, finance. Phone: +382 20241 138. Fax: +382 20244 588. E-mail: savana@t-com.me (corresponding author).
} 


\section{Introduction}

Insurance business has a positive impact on economic development and vice versa. As a developed insurance market stimulates economic growth of a country, the level of its economic growth affects insurance business development in return. In recent decades, demand for life insurance is characterized by continuous growth. For this reason, there are numerous theoretical and empirical researches tending to prove that different factors influence life insurance demand. Factors which are key determinants of life insurance demand can be classified as economic (GDP, incomes, employment, inflation etc.); demographic (age, sex, region, education etc.) and political, i.e. legal factors (corruption, the rule of law etc.) (Sen and Madheswaran, 2013; Sen, 2007; Hwang and Greenford, 2005; Zietz, 2003; Beck and Webb, 2003).

For the analysis of life insurance development trend, besides the above-listed factors, it is important to observe the trust of the population and industry in overall insurance sector. Responsibility, safety and stability of insurance companies business, affect the growth of population's trust in saving through life insurance products. Also, general knowledge and awareness of people regarding the significance and necessity of life insurance products possession influence the development level of the market itself significantly. In order to have a sufficiently developed insurance sector, it is necessary to educate the population, develop insurance culture and encourage the feeling of individual responsibility for the provision of personal and family financial security through various forms of savings, life insurance policy definitely being one of them. Insurance development also depends on the development and stability of financial market.

Insurance market in Western Balkans is characterized by significant changes caused by different economic growth pace. Countries preparing to enter the European Union carry out faster reforms and there is also a significant entrance of foreign capital due to the reduction of financial and political risks. Insurance sector analysis in these countries is best realized through comparison of insurance development basic indicators (insurance premium, penetration and insurance density, market concentration etc.), analysis of deviations from indicator values for observed markets compared to insurance markets of developed EU countries, as well as the prognosis of future insurance development through basic market segments, i.e. life and non-life insurance. Although the situation on insurance markets of the Western Balkan countries is not on a satisfying level, it is expected that the approach of these countries to the European Union will contribute to their economic development and, therefore, to the development of life insurance.

The aim of this work is to point at the most important economic factors which determine life insurance trends in Western Balkan countries. The factors taken into account are: GDP, unemployment, incomes and passive bank interest rate. The 
authors' motivation for starting this research is based on the occasion that the level of the stability of the both financial system and economic development of a country is significantly qualified by the sector of life insurance. As it is necessary to analyse the influence of the macroeconomic indicators for the estimation and the control of a potential systemic risk of the insurance companies and generally its business, the authors considered both important and interesting to observe the region of the Western Balkan in the context of this issue. Many authors analysed the link between economic growth and insurance market using certain econometric models and confirmed the significance of this research topic (Bianchi et al. 2011; Haiss and Sümegi, 2008; Sen, 2007; Kugler and Ofoghi, 2005; Ward and Zurbruegg, 2002).

The paper tends to prove hypothesis that economic factors, i.e. GDP, unemployment, incomes and interest rate, significantly affect the demand for life insurance in Western Balkan countries.

The main contribution of the paper is a conducted research of the impact of key economic factors on the demand for life insurance, which can be useful for institutions and regulators of financial system, economic analysts and other subjects in the countries of Western Balkans, in order to carry out timely analyses and prognosis of life insurance market development trend, i.e. possible measures in order to upgrade it further. Also, according to our knowledge, this kind of research including Montenegro besides other Western Balkan countries has not been carried out so far, which is a proof of an important contribution of this manuscript.

This paper consists of sixth parts. After the introductory part, there is literature review. The third part of the paper offers the description of the methodology. Data description and empirical analysis of the impact of economic factors on life insurance premium are described in forth part of the paper. The fifth part of the paper, before conclusions as the final part, presents empirical results of the model used in this manuscript.

\section{Literature review}

Factors influencing life insurance development differ depending on the country where they are studied. More than 20 empirical academic studies have been published on the effect of key factors on demand for life insurance. These factors are: demographic, macroeconomic, social and psychological, institutional, as well as those depending on the insurers themselves (Zietz, 2003). Many authors indicate to the importance of inflation rate, available income of citizens, financial development of the country, social security, as well as population (for example, birthrate, life expectancy, educational level, etc.), on life insurance trends (Beck and Webb, 2003; Browne and Kim, 1993; Hwang and Greenford, 2005; Outreville, 
1996). For example, Sen (2007) estimated that there is a certain impact of GDP, GDS (gross domestic savings) per capita, urbanization, adult literacy, life expectancy at birth, mortality rate, inflation, real interest rate and the price of insurance on the demand for life insurance in Asian countries, and showed that there is a significant positive relation between life insurance premium and gross domestic savings, income per capita and financial development of the country, while inflation has a negative impact on life insurance. Sen and Madheswaran (2013) analyze the factors explaining life insurance demand in 12 Asian economies too. The results suggest that income, inflation, interest rate, and the youth dependency ratio are significant determinants of life insurance consumption.

Dragos (2014) estimates that a significant impact on the development of both life and non-life insurance has the income and its distribution among population. Using econometrics of panel data for 17 countries in Asia and Central Eastern Europe in the period of 10 years, she proved that the income has a positive impact on demand for insurance in CEE countries, while it has no significant impact on developing Asian countries. Feyen et al. (2011), consider that the reason of the positive impact on demand for life insurance is also the necessity of employed parents to secure their children against the risk of parents' early death. Not only the income, but also the distribution on the level of country can have a significant impact on aggregate demand for insurance. The inequality of income distribution is in inverse proportion to life insurance penetration, but the demand for life insurance depends on the interaction between the levels of income and the type of its distribution, which indicates that income distribution inequality may have an ambiguous impact on demand for life insurance (Nakata and Sawada, 2007). Analyzing 10 OECD economies for the period 1970-1981, using panel study, Beenstock et al. (1986) discovered that rich people don't need risk protection through insurance, while poor people have limited financial abilities, i.e. they concluded that middle class of the population has the highest interest in life insurance products. Further, they concluded that a more equal distribution of income increases the middle class of the population and therefore it has a positive impact on demand for life insurance. Beck and Webb (2003) analyzed 68 countries (1961-2000) and reached the opposite conclusion. Rich population has a need for life insurance in order to secure their descendants. Uniform distribution of income among population leads to the growth of middle class. However, a minimum disposable income amount is necessary for the members of middle class to be able to afford life insurance. More accurately, according to these authors, middle class is not the target group for life insurance purchase and they conclude that there is a negative correlation between demand for life insurance and uniform income distribution.

Truett and Truett (1990) compared in this research demand for life insurance in Mexico and America using time regression. They proved that the income is in a positive correlation with demand for life insurance and that income elasticity of 
demand for life insurance is much higher in Mexico than in America. Browne and Kim (1993) investigated factors influencing the demand for life insurance through regression analysis in 1980 and 1987. As an income measure they used available income. The research showed that the income is a variable statistically significant and positively correlated in all applied models, so they confirmed the positive correlation between income and demand for life insurance. The impact of interest rate on demand for life insurance was disregarded. Li et al. (2007) came to conclusion that demand for life insurance is positively correlated with income, education and financial development of the country, while there is a negative connection between inflation and interest rate on financial market. They carried out the research on 30 OECD countries in the period between 1993 and 2000. Kjosevski (2012) analyzed the determinants of life insurance demand in panel of 14 countries in Central and South- Eastern Europe over the period 1998 - 2010, using two indicators of life insurance demand, life insurance penetration and life insurance density. He found that life insurance penetration and life insurance density increase with higher per-capita income. As overall income level and the share of middle class rise, demand for life insurance may be expected to rise, too. The results of his research have also shown that real interest rate on the market, education and the rule of law have a positive impact on demand for life insurance, while financial development of a country is statistically insignificant. Zerriaa and Noubbigh (2016) analysed determinants of Life Insurance Demand in the Middle East and North Africa region (MENA region). They used two measures of life insurance demand: insurance density and insurance penetration. The research results suggest that consumption increases with income, inflation and interest rates.

Luciano et al. (2016) analyzed the ownership of life insurance products by Italian households and showed that demand for insurance is highly correlated with income, family structure and employment status. Lee and Chiu (2012) apply panel smooth transition regression model (PSTR) and take into account the potential endogeneity biases in order to establish country-specific and timespecific elasticities of insurance premiums with respect to real income for 36 selected countries from the period 1979-2007. They found that the life and non-life insurance premiums are inelastic and elastic with respect to real income, suggesting that they are necessary goods and luxury goods respectively. Furthermore, as time goes on, the income elasticities of insurance premiums present a similar upward trend, implying that the impact of economic development on insurance premiums has been more important in recent periods.

Ward and Zurbruegg (2002) in their research investigate the correlation between economic development and demand for life insurance in nine OECD countries in the period between 1961 and 1966. As a measure of economic development they took real GDP and as a measure of demand, they used total life insurance premium. The research showed that the consumption of life insurance products 
in Asia is under stronger influence of GDP than it is the case in OECD countries, which means that economic development cannot be taken as a determinant when bringing decisions on demand for life insurance. Kugler and Ofoghi (2005) in their research examined the link between economic growth and insurance markets size for the UK in the long-run. The results confirm that long-run relationship between economic growth and insurance market size development is significant for majority of all variables. The relation between insurance market development and economic growth was investigated by Haiss and Sümegi (2008). They identified a positive correlation between expenditure in non-life insurance premiums (as life insurance had not been not developed at a sufficient level yet) and GDP also in SEE countries. Enz (2000) also investigated the correlation between economic development and demand for life insurance. Using S-curve, he showed that demand for life insurance has a tendency of growth when the state economy grows, but as time passes and this state's economy reaches the level of developed countries, the demand for life insurance slows down. He also suggested the use of econometric models for longterm premium forecast based on GDP projections. Bianchi et al. (2011) examined the influence of GDP growth on insurance premium growth in Central, Eastern and Southeastern Europe (CESEE). Using a panel regression (cross-section with fixed effects), where real premium growth was explained by GDP growth, they show that potential growth of the insurance market in CESEE is closely connected with economic growth in the region. Higher growth is often related with higher risk, which implies that in case of an economic downturn, premium growth rates might decrease equally strongly. Furthermore, heightened financial market tensions and weakening economic conditions in advanced economies could considerably slow down insurance growth.

Very few studies were available on the insurance markets of Western Balkans until the 1990s done by authors from the SEE countries, and only by a few authors from Western Europe and United States. On the other hand, many academics considered transition process of Western Balkan countries as important field for research, even if much more interest was shown in the development of the banking industry.

\section{Methodology}

This part of the manuscript describes methodology of the research. Econometric model of panel data was constructed for 6 countries (Albania, Bosnia and Hercegovina, Croatia, Macedonia, Montenegro and Serbia) concluded the period of 11 years (2005-2015). The analysis will prove or refute the previous hypothesis and supplement existing research on demand for life insurance in different countries.

Consider the multiple linear regression model for individual $i=1, \ldots . \mathrm{N}$ which is observed at several time periods $t=1, \ldots . \mathrm{T}$ 


$$
y_{i t}=\alpha+x_{i t}^{\prime} \beta+z_{i}^{\prime}+c_{i}+u_{i t}
$$

Where $y_{i t}$ is the dependent variable, $x_{i t}^{\prime}$ is a K-dimensional row vector of timevarying explanatory variables and $z_{i}^{\prime}$ is a M-dimensional row vector of timeinvariant explanatory variables excluding the constant, $\alpha$ is the intercept, $\beta$ is a $\mathrm{K}$-dimensional column vector of parameters, $\gamma$ is for M-dimensional column vectors of parameters, $c_{i}$ is an individual - specific effect and $u_{i t}$ is an idiosyncratic error term.

We will assume throughout this paper that each individual $i$ is observed in all time periods $t$. This is a so-called balanced panel. Fixed effects and random effects models are considered for this analysis but after detailed analysis we have chosen the random effect model (the Hausman test). Both models work to remove omitted variable bias by measuring change within a group. By measuring within a group (across time) we control for a number of potential omitted variables unique to the group.

Under the random-effects model the goal is not to estimate one true effect, but to estimate the mean of a distribution of effects. Since each study provides information about a different effect size, we want to be sure that all these effect sizes are represented in the summary estimate.

Since the Random Effects Model is applied, in its form the individual - specific effect is a random variable that is uncorrelated with the explanatory variables.

Variables of the model are: logarithm of Life Premium ( $\operatorname{lnLP})$ as dependent variable and Gross Domestic Product (GDP), Unemployment rate (U-RATE), wages (WAGES) and interest rates (INTR) as Independent variables.

\section{Empirical data and analysis}

\subsection{Data}

The data used in this research are taken from official reports of regulatory institutions on financial market and statistics institutes of Western Balkan countries.

Economic development of a country, which can be measured through GDP and incomes, represents a key economic determinant of life insurance demand. As an economy develops, life standard grows, as well as demand for life insurance products. Higher the income, life insurance products become more available to citizens of every country. They change the list of their needs and instead of considering satisfaction of some basic needs, their preferences change towards family, health, old age, property protection. The drop in life standard and higher 
unemployment rate has caused that most citizens turn to mainly existential priority list, while only the citizens with higher incomes, i.e. wages, consider insurance.

Economic indicators are recorded based on yearly reports of central (national) banks and statistics agencies of the countries observed. The trends of most important economic indicators in Western Balkan countries (GDP, unemployment and wages) in the period 2005-2015 are shown in Figures 1, 2 and 3.

Figure 1: GDP in Western Balkan Countries

- in mil. $€$

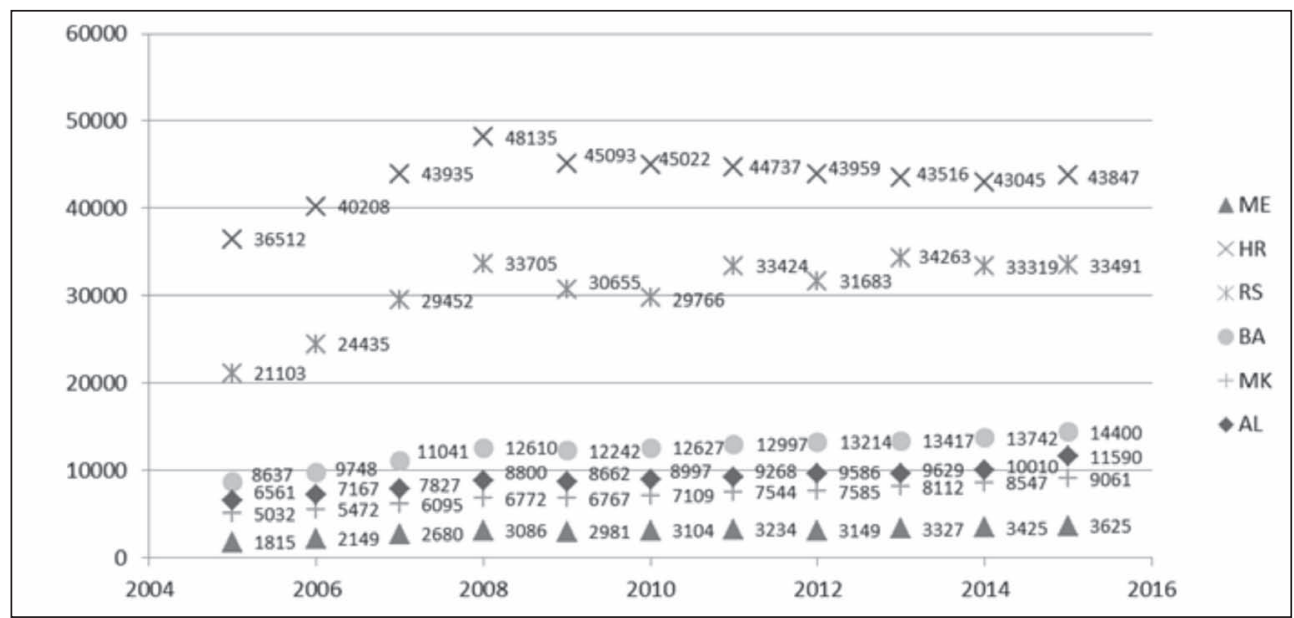

Source: National Bank of Serbia, Croatian Insurance Bureau, Statistical Agency of Bosna and Herz., National Bank of Macedonia and State Statistical Office of the Republic of Macedonia, Monstat Montenegro, Bank of Albania

Figure 1 clearly shows that Croatia has the highest GDP of all observed countries, while according to this indicator, Serbia is behind it, and Montenegro is in the last place. It is also observed that up to the period of the financial crisis, GDP had grown in all observed countries. In 2008, compared to the previous year, the GDP obviously declined, which on average was about $12 \%$ for all countries observed. 
Milijana Novović Burić et al. • Impact of economic factors on life insurance development...

Figure 2: Unemployment rates in Western Balkan countries

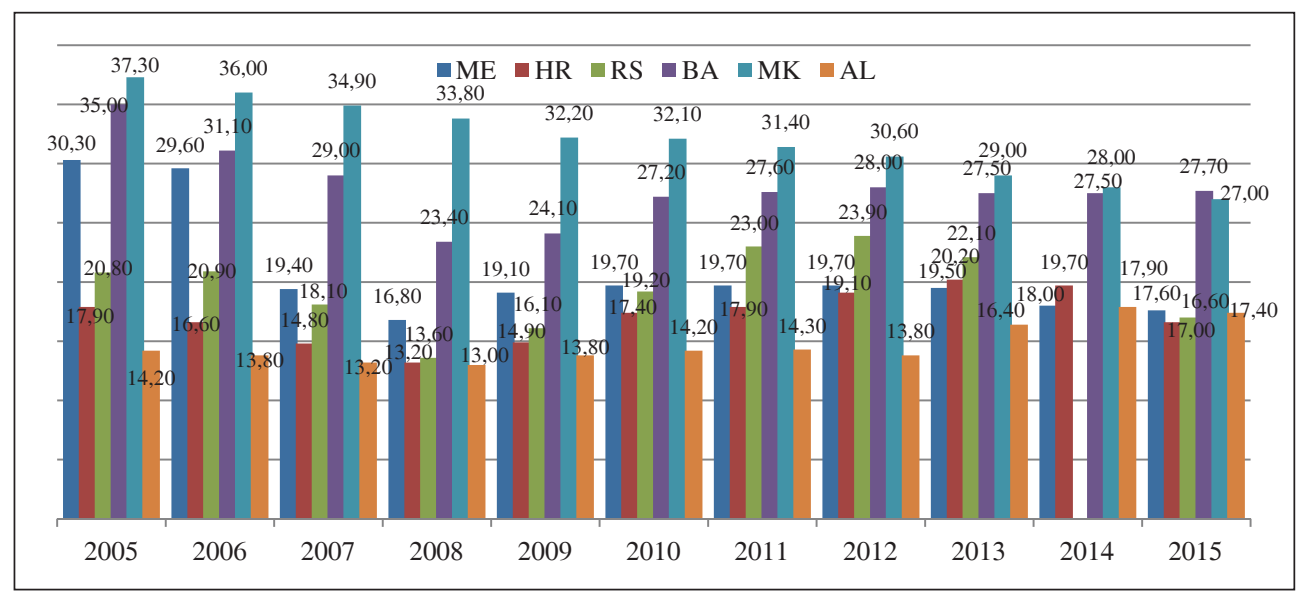

Source: National Bank of Serbia, Croatian Insurance Bureau, Agency for Statistics of Bosna and Herz., National Bank of Macedonia and State Statistical Office of the Republic of Macedonia, Monstat Montenegro, Bank of Albania

By analyzing the data given in Figure 2, we come to the conclusion that Bosnia and Herzegovina and Macedonia have the highest unemployment rate in the observed period. At the same time, it is observed that, of all Western Balkan countries, Montenegro is characterized by the highest decrease of the unemployment rate (42\% in 2015 compared to 2005), while such a trend is not present in other countries (for example, in Albania there is an increase in the unemployment rate of $22,5 \%$ in 2015 compared to 2005 ).

Figure 3: Average net wages in Western Balkan countries

- in $€$

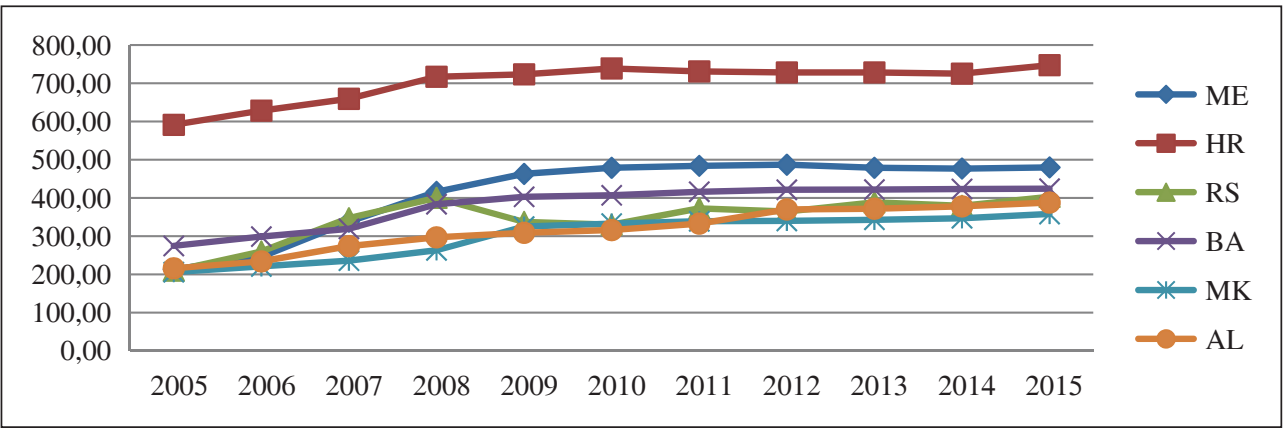

Source: National Bank of Serbia, Croatian Insurance Bureau, Agency for Statistics of BIH, National Bank of Macedonia and State Statistical Office of the Republic of Macedonia, Monstat Montenegro, Bank of Albania 
From Figure 3 it can be noted that Croatia has the highest average net wage, which is expected due to the overall macroeconomic ambient of this country, while Macedonian and Albanian net wages are the lowest. In all countries, wages grew in 2015 compared to the beginning of 2005, with the highest increase in Montenegro (about 55\%) and the lowest in Croatia (about 21\%). In other countries, this growth was on average about $42 \%$ (in 2015 compared to 2005).

Financial market interest rate is a variable with a positive, but also a negative influence on life insurance demand. Interest rate growth causes the growth in financial yield and decrease in demand for life insurance (Kascelan and Novovic, 2009). However, interest growth increase can direct citizens to investing their financial resources into alternative financial instruments on the market or other forms of savings, which definitely leads to the reduction of demand for life insurance. The influence of interest rate on life insurance demand depends on whether average interest rate on financial market is being analyzed and tested (which is definitely hard to evaluate), or deposits interest rate, state bonds interest rate or some other kind of interest rate. Due to insufficient development of financial markets and weak offer of financial instruments in Western Balkan countries, as well as due to the fact that insurance companies from these countries deposit most of their reserved resources, i.e. term deposit with banks, the manuscript uses average weighted passive interest rate of banks on a yearly level (interest rates on deposits). The variable is obtained, i.e. calculated based on data reported by central banks of the countries observed shown in Table 1.

Table 1: Yearly passive interest rates of banks in Western Balkan countries

\begin{tabular}{|l|r|r|r|r|r|r|r|r|r|r|r|}
\hline \multicolumn{1}{|c|}{ Year } & 2005 & 2006 & 2007 & 2008 & 2009 & 2010 & 2011 & 2012 & 2013 & 2014 & 2015 \\
\hline ME & 3.60 & 4.67 & 3.35 & 3.88 & 3.78 & 3.70 & 3.13 & 3.26 & 2.91 & 2.14 & 1.48 \\
\hline HR & 2.91 & 2.91 & 3.14 & 3.41 & 3.51 & 2.50 & 2.34 & 2.24 & 1.92 & 3.02 & 2.75 \\
\hline RS & 3.71 & 5.06 & 4.08 & 7.32 & 5.06 & 5.55 & 5.40 & 5.04 & 4.30 & 3.09 & 2.11 \\
\hline BA & 2.03 & 2.10 & 2.10 & 2.33 & 2.00 & 1.83 & 1.74 & 2.38 & 2.33 & 1.79 & 1.26 \\
\hline MK & 5.20 & 4.70 & 4.90 & 5.90 & 7.00 & 7.00 & 5.90 & 5.10 & 4.40 & 3.70 & 2.90 \\
\hline AL & 5.18 & 4.95 & 4.43 & 4.82 & 4.95 & 4.72 & 4.36 & 3.98 & 3.13 & 1.65 & 1.18 \\
\hline
\end{tabular}

Source: Authors' calculation based on data on interest rates given in reports of Western Balkan central banks

If we observe life insurance markets in Western Balkans, we can notice that in all these countries they have recorded a moderate growth in the recent decade. However, in comparison with the EU countries, these indicators are still below the average. The data on insurance indicators are taken from the reports of Insurance Supervisory Agencies of Montenegro, Bosnia and Herzegovina and Macedonia, i.e. the National Bank of Serbia, Croatian Insurance Bureau and Albanian Financial Supervisory Agency. (Table A1 and Table A2 in Appendix) 


\subsection{Empirical analysis}

The appropriateness of the data for panel analysis should be checked at the very beginning. Therefore, the first phase of our analysis includes testing the stationarity of all variables included in the model. Independent variables are left in the original form, while the level of dependent variable was made as a logarithm (just in order to make this variable stationary).

In order to test for unit roots in our model, we used Levin-Lin-Chu test that has as the null hypothesis that all the panels contain a unit root.

Table 2: Unit root test results

\begin{tabular}{|c|c|c|c|c|c|}
\hline $\begin{array}{ll}\text { Test results } & \text { Variables }\end{array}$ & Lnlp & gdp & urate & Wages & Intr \\
\hline Levin, Lin \& Chu statistics & $-4.28237^{*}$ & $-4.43402^{*}$ & $-8.18803^{*}$ & $-24.5304^{*}$ & $-3.2265^{*}$ \\
\hline ADF - Fisher Chi-square & $28.9152^{*}$ & $22.8686^{*}$ & $34.5914^{*}$ & $36.8905^{*}$ & $27.4518^{*}$ \\
\hline Probability $^{*}$ & & Sig & cee at & vel & \\
\hline
\end{tabular}

Note: Results from R package

Source: Authors' calculation

The Levin-Lin-Chu statistics are reported in the above table. As stated in Table 2, statistics for all variables are significant at all the usual testing levels $(5 \%$ significance). Therefore, we reject the null hypothesis and conclude stationarity of all series in the model. The same results we got from testing stationarity using ADF-Fisher Chi-square statistics. The values of ADF-Fisher Chi-square statistics reported in Table 2 for each variable suggest that a unit root can be rejected at least at the 5 percent level.

Now, after successful tests of unit root, we can go on to modelling.

We tested whether there is a significant influence of some typical economic indicators on insurance premium. We used a lot of indicators and several of them confirmed to be statistically relevant for the development of the insurance market. The dependent variable of our model is insurance premium (in logarithm, $\operatorname{lnLP}$ ) and independent variables are: nominal gross domestic product (GDP), unemployment rate (U-rate), gross wages (wages), interest rates (INTR). We estimated a panel data model with fixed and random effects, and used the best model in terms of statistical rules.

In order to choose between fixed effects model and random effects model in panel data, we used the Hausman test. Random effects model is preferred under the null hypothesis due to higher efficiency. The alternative hypothesis means that fixed effects model is at least consistent and preferred. In Table 3, results of the Hausman test are presented to confirm adequate choice of random effect model. 
Table 3: Hausman test for the Model

\begin{tabular}{|c|c|c|}
\hline Chisquare & Degrees of freedom & P-value \\
\hline 0.0308 & 4 & 0.9847 \\
\hline
\end{tabular}

Note: Results from R package

Source: Authors' calculation

As the results of the Hausman test state, the null hypothesis cannot be rejected and therefore we use the model with random effects.

We can now show the most appropriate model that will help us to explain the relationship within economic and life insurance development. In order to get more reasonable interpretation of the results, we used log linear model with dependent variable transformed into logs. The best model in terms of statistical rules is model with random effects and is presented in the Table 4.

Table 4: Empirical results of panel data model 1 with random effects for life insurance premium

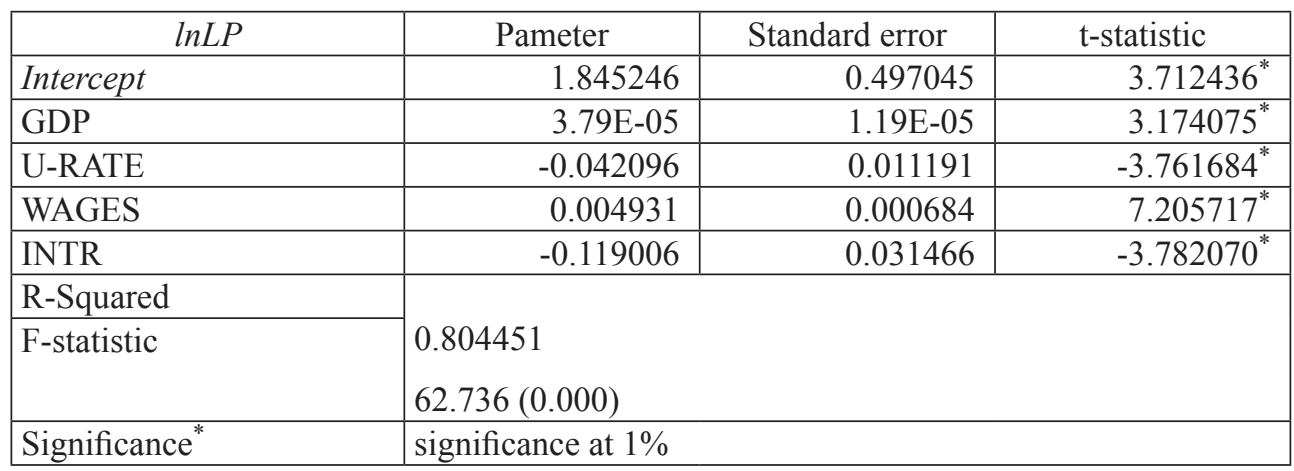

Note: Results from R package

Source: Authors' calculation

Its results show the examined influences of explanatory variables (GDP, unemployment, income and interest rates) to life insurance development measured by logarithm of life insurance premium.

\section{Results and discussion}

Life insurance has an increasingly important role on financial market, so the demand for this insurance product is the subject of numerous theoretical and empirical studies. Low share of life insurance premium in total insurance portfolio, as well as 
other market indicators, clearly indicate insufficiently developed insurance sector of Western Balkan countries compared to other developed countries. The main aim of this manuscript was to identify the factors affecting demand for life insurance and investigate their meaning on the sample of Western Balkan countries in the period of 11 years. Also, this manuscript tends to show and analyze life insurance market of observed countries.

The aforementioned results clearly state that insurance premium is significantly influenced by all these relevant economic indicators and therefore confirm the importance of economic environment for the development of the insurance market.

Therefore, in the given period of 11 years (2005-2015), in analyzed countries of Western Balkans, there was a statistically significant impact of all given variables (GDP, unemployment rate, wages, interest rates) on the demand for life insurance.

Global economic deviations impact the demand for insurance services in a negative way, as well as investment scope and the role of insurance companies as institutional investors, both in Western Balkans and in other developed countries worldwide. Higher GDP growth rate causes the growth of economic activities, leading to the premises regarding positive correlation between GDP growth rate and demand for life insurance. As it can be observed in the Table 4, GDP has a positive impact on demand for life insurance in Western Balkan countries. Authors Ward and Zurbruegg (2002), Enz (2000) and Sen (2007) came to this result. GDP growth trend leads to employment and income growth, while the income growth itself leads to the increase in savings, which definitely indicates to potential growth in life insurance demand. From Table 4 we can learn that this research has shown that incomes do have a significant and positive impact on demand for life insurance, but much more than GDP. Many authors have shown in their researches that there is a significant and positive impact of incomes on demand for life insurance, such as Sen and Madheswaran (2013), Dragos (2014), Feyen et al. (2011) and others.

On the other hand, our model has shown that unemployment rate and interest rate have a negative impact on demand for life insurance, just like authors Li et al. (2007). Higher unemployment leads to the drop in citizens' incomes and free financial assets which it would be possible to place in some form of savings, such as life insurance. In accordance with actuarial bases of insurance tariffs calculation, interest rate growth according to which reserves are accumulated, can lead to life insurance product price drop. However, taking into account other parameters as well, affecting the demand for life insurance in developing countries (for example, income level, trust in financial system and insurance market, education of the population and knowledge of the significance of life insurance products etc.), this reduction in life insurance price does not necessarily cause the increase in demand for life insurance. Taking into account life standard and general economic environment in developing countries, it is more realistic to expect the growth of 
bank interest rate to direct citizens to term deposit their free assets with banks instead of placing them in purchase of life insurance premiums, which was proven by panel analysis carried out in this manuscript.

Economic and social situation in observed countries have caused the life insurance premium not to be on a sufficient level compared to other developed countries in Europe and worldwide. In order to mitigate problems insurance companies face, besides activities of insurance companies themselves, such as coordination of life insurance products offer in accordance with needs and financial solvency of citizens, it is necessary that every country through special subventions shows particular interest in its further development.

Even though it is not easy to assess the link between macroeconomic determinants and insurance sector, the results of this research can give important recommendations and suggestions for policy-makers and regulators who should pay more attention to estimate the macroeconomic indicators and life insurance trends in the times of financial instability and economic crisis. Also, the results could be useful for insurers in order to detect and quantify possible economic situations affecting insurance companies' balance sheets.

\section{Conclusions}

The results of the investigations contained in this manuscript have shown that insufficient development of life insurance is a direct consequence of slowed process of overall economic reforms, i.e. economic underdevelopment, unemployment and low purchasing power. GDP growth increases investment and demand for insurance. With life insurance being a significant form of saving and security against risk, it is logical that with life standard growth, especially the incomes of population, total paid life insurance premium also increases. Due to higher income, especially younger, educated population with adequate employment will have an opportunity to use a part of their income for purchase of life insurance products. Higher unemployment in the country has a negative impact on life insurance demand, which is explained by drop in economic activities and life standard, i.e. number of potential policy holders. More precisely, higher employment rate, growth of personal incomes and general improvement of life standard in Western Balkan countries, impact further development of life insurance positively.

Western Balkan countries' insurance companies mainly deposit free assets of their reserves in banks, so the placement yields are mainly realized based on interest rates of term deposits. With average interest rate growth on financial market, insurance companies realize significant incomes from placements which can reduce the price of insurance, but are also distributed among users after the insured sums are paid and then to stock holders in smaller amounts, which should have a positive 
impact on citizens' perception of life insurance benefits, i.e. on the life insurance market itself. On the other hand, taking into account primarily life standard of citizens in the observed countries, it is clear that the main motive of most citizens is to realize as much yield as possible from placements of their free financial assets. If banks increase their interest rates on deposits, it is clear that citizens will direct their savings to banks because placements yields with banks are higher than insured sum which can be expected from life insurance companies.

We can conclude that hypothesis defined in the manuscript is proved. However, it is important to note that panel analysis is limited to the period of 11 years (20052015) and it is mainly characterized by global financial crisis which started in the middle of year 2007 in the USA. Due to the fact that most countries of Western Balkans came to existence at the end of the 20th century and beginning of the 21st century after the disintegration of Federal Republic of Yugoslavia, the authors of this paper were not able to consider a wider time period, i.e. a bigger sample, and this is the main shortcoming of the analysis.

However, this manuscript also opens other interesting research questions in the field of life insurance for Western Balkan countries. Besides the impact of economic factors, the development of life insurance should also be analyzed from the aspect of, for example, demographic and political factors impact in these countries. Also, it would be interesting to observe Western Balkan countries in a wider European frame and compare the results of this manuscript with the new panel analysis, which would be one of the topics of future research of this manuscript's authors.

\section{References}

Beck, T., Webb, I. (2003) "Economic, demographic and institutional determinants of life insurance consumption", The World Bank Economic Review, Vol. 17, No. 1, pp. 51-88., doi: 10.1093/wber/lhg011.

Beenstock, M., Dickinson, G., Khajuria, S. (1986) "The determination of life premiums: An international cross-section analysis, 1970-1981", Insurance: Mathematics and Economics, Vol. 5, No. 4, pp. 261-270, doi: 10.1016/01676687(86)90020-X.

Bianchi, T. et al. (2011) "The Austrian Insurance Industry in CESEE: Risks and Opportunities from a Financial Stability Point of View." Financial Stability Report 22 [Internet], pp. 88-106, Available at: <https://www.oenb.at/dam/ jcr:906a8eb5-0db6-4492-b257-8b9521ec7328/fsr_22_special_topics_03_ tcm16-242315.pdf > [Accessed: January 21, 2017].

Browne, M. J., Kim, K. (1993) “An International Analysis of Life Insurance Demand", Journal of Risk and Insurance, Vol. 60, No. 4, pp. 616-634, doi: $10.2307 / 253382$. 
Dragos, S.E. (2014) "Life and non-life insurance demand: the different effects of influence factors in emerging countries from Europe and Asia", Economic Research Ekonomska Istraživanja, Vol. 27, No. 1, pp. 169-180, doi: 10.1080/1331677x.2014.952112.

Enz, R. (2000) "The S-curve Relation Between Per-Capita Income and Insurance Penetration", Geneva papers on risk and insurance-Issues and Practice, Vol. 25, No. 3, pp. 396-406, doi: 10.1111/1468-0440.00072.

Feyen, E., Lester, R., Rocha, R. (2011) "What drives the development of the insurance sector? An empirical analysis based on a panel of developed and developing Countries", Policy Research Working Papers, doi: 10.1596/18139450-5572.

Haiss, P., Sümegi, K. (2008) “The Relationship Between Insurance and Economic Growth in Europe: A Theoretical and Empirical Analysis“, Empirica, Vol. 35, No. 4, pp. 405-431, doi: 10.1007/s10663-008-9075-2.

Hwang, T., Greenford, B. (2005) "A Cross-Section Analysis of the Determinants of Life Insurance Consumption in Mainland China, Hong Kong, and Taiwan", Risk Management and Insurance Review, Vol. 8, No. 1, pp. 103-125, doi: 10.1111/j.1540-6296.2005.00051.x.

Kašćelan V., Novović M. (2009) Osiguranje i aktuarska matematika, I izdanje, Univerzitet Crne Gore, Podgorica.

Kjosevski, J. (2012) "The determinants of life insurance demand in central and Southeastern Europe", International Journal of Economics and Finance, Vol. 4, No. 3, pp. 237-247, doi: 10.5539/ijef.v4n3p237.

Kugler, M., Ofoghi, R. (2005) "Does Insurance Promote Economic Growth? Evidence from the UK" Money Macro and Finance (MMF) Research Group Conference [Internet], pp. 1-27, Available at: < http://repec.org/mmfc05/paper8. pdf $>$ (Accessed on December 4, 2016).

Lee, C., Chiu, Y. (2012) "The impact of real income on insurance premiums: Evidence from panel data", International Review of Economics \& Finance, Vol. 21, No. 1, 246-260, doi: 10.1016/j.iref.2011.07.003.

Levin, A., Lin, C.F., Chu, C-S.J. (2002) "Unit root tests in panel data: Asymptotic and finite sample properties", Journal of Econometrics, Vol. 108, No. 1, pp. 1-22, doi: 10.1016/s0304-4076(01)00098-7.

Li, D. et al. (2007) "The Demand for Life Insurance in OECD Countries", The Journal of Risk and Insurance, Vol. 74, No. 3, pp. 637-652, doi: 10.1111/j.1539-6975.2007.00228.x.

Luciano E., Outreville J.F., Rossi M. (2016) "Life Insurance Ownership by Italian Households: A Gender-Based Differences Analysis", The Geneva Papers on Risk and Insurance - Issues and Practice, Vol. 41, No. 3, pp. 468-490, doi: 10.1057/gpp.2016.7. 
Nakata, H., Y. Sawada (2007) "Demand for Non-life Insurance: A Cross-Country Analysis", Working Paper, Centre for International Research of the Japanese Economy CIRJE-F-461, University of Tokyo, [Internet], pp.1-9 Available at: $<$ http://www.cirje.e.u-tokyo.ac.jp/research/dp/2007/2007cf461.pdf $>$ [Accessed: December 17, 2016].

Outreville, F. J. (1996) "Life Insurance Markets in Developing Countries", Journal of Risk and Insurance, Vol. 63, No. 2, pp. 263-278, doi: 10.2307/253745.

Sen, S. (2007) "Are Life Insurance Demand Determinants valid for Selected Asian Economies and India?" Institute for Social and Economic Change. Paper for Presentation at Annual Meeting of APRIA, [Internet], pp. 1-27, Available at: $<$ :https://www.scribd.com/document/230968492/13507Paper-APRIA-SubirDraft $>$ [Accessed: February 11, 2017].

Sen, S., Madheswaran, S. (2013) "Regional determinants of life insurance consumption: evidence from selected Asian economies", Asian-Pacific Economic Literature, Vol. 27, No. 2, pp. 86-103, doi: 10.1111/apel.12024.

Truett D.B., Truett L.J. (1990) "The Demand for Life Insurance in Mexico and the United States: A Comparative Study", The Journal of Risk and Insurance, Vol. 57, No. 2, pp. 321-328, doi: 10.2307/253306.

Ward, D., Zurbruegg, R. (2002) "Law, Politics and Life Insurance Consumption in Asia", Geneva Papers on Risk and Insurance, Vol. 27, No. 3, pp. 395-412. doi: 10.1111/1468-0440.00181.

Zerriaa,M., Noubbigh, H. (2016) "Determinants of Life Insurance Demand in the MENA Region", The Geneva Papers on Risk and Insurance - Issues and Practice, Vol. 41, No. 3, pp. 491-511, doi: 10.1057/gpp.2016.1.

Zietz, E. N. (2003) "An examination of the demand for life insurance", Risk Management and Insurance Review, Vol. 6, No. 2, pp. 159-191, doi: 10.1046/j.1098-1616.2003.030.x. 
Milijana Novović Burić et al. • Impact of economic factors on life insurance development...

\title{
Utjecaj ekonomskih čimbenika na razvoj životnog osiguranja u zemljama Zapadnog Balkana
}

\author{
Milijana Novović Burić ${ }^{1}$, Julija Cerović Smolović ${ }^{2}$, Milena Lipovina Božović3 \\ Ana Lalević Filipović ${ }^{4}$
}

\begin{abstract}
Sažetak
Tržište životnog osiguranja u zemljama Zapadnog Balkana nije dovoljno razvijeno u usporedbi s drugim europskim zemljama, ali u posljednjih desetak godina ostvaruje umjereni rast $i$ to pod utjecajem raznih čimbenika, prije svega ekonomskih, a zatim demografskih, političkih $i$ drugih. Cilj rada je analizirati $i$ ukazati na najvažnije ekonomske čimbenike koji imaju značajan utjecaj na kupnju proizvoda životnog osiguranja. Da bi se dokazala hipoteza postavljena u radu, primjenjuje se model panel analiza podataka kako bi se ispitao utjecaj BDP-a, stope nezaposlenosti, plaće i kamatne stope na ukupne premije životnog osiguranja u zapadnom Balkanu u razdoblju od 2005. do 2015. godine. Rezultati analize potvrđuju da navedeni ekonomski čimbenici uglavnom utječu na ukupnu premiju životnog osiguranja u zemljama zapadnog Balkana. BDP i plaće imaju značajan $i$ pozitivan utjecaj na potražnju za životnim osiguranjem, dok je utjecaj stope nezaposlenosti i kamatne stope negativan.
\end{abstract}

Ključne riječi: tržište životnog osiguranja, ekonomski čimbenici, premija osiguranja, model panel analize, Zapadni Balkan

JEL klasifikacija: G22, C23, O52,O11

${ }^{1}$ Docentica, Sveučilište u Crnoj Gori, Ekonomski fakultet, Jovana Tomaševića 37, 81000 Podgorica. Znanstveni interes: financije, osiguranja, računovodstvo. Tel.: +382 20241138. Fax:+382 20244 588.E-mail:mnovovic@ac.me.

${ }^{2}$ Asistentica, Sveučilište u Crnoj Gori, Ekonomski fakultet, Jovana Tomaševića 37, 81000 Podgorica. Znanstveni interes: financije, statistika, matematika. Tel.: +382 20241 138. Fax: +382 20244 588.E-mail: julija@ac.me.

3 Asistentica, Sveučilište u Crnoj Gori, Ekonomski fakultet, Jovana Tomaševića 37, 81000 Podgorica. Znanstveni interes: makroekonomija, statistika, matematika. Tel.: +382 20241 138.Fax:+38220244 588.E-mail:mlipovina.bozovic@googlemail.com.

4 Izvanredna profesorica, Sveučilište u Crnoj Gori, Ekonomski fakultet, Jovana Tomaševića 37, 81000 Podgorica. Znanstveni interes: računovodstvo, financije.Tel.: +382 20241 138. Fax: +38220244 588.E-mail: savana@t-com.me (osoba za kontakt). 
Milijana Novović Burić et al. • Impact of economic factors on life insurance development...

\section{Appendices}


Milijana Novović Burić et al. • Impact of economic factors on life insurance development... Zb. rad. Ekon. fak. Rij. • $2017 \cdot$ vol. $35 \cdot$ no. $2 \cdot 331-352$ 


\begin{tabular}{|c|c|c|c|c|c|c|c|c|c|c|c|c|}
\hline \multirow{4}{*}{$\begin{array}{c}\frac{\pi}{0} \\
\frac{0}{0} \\
\tilde{D}\end{array}$} & 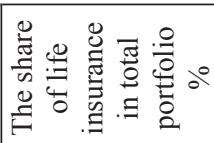 & $\stackrel{8}{\circ}$ & $\stackrel{8}{\circ}$ & $\stackrel{8}{\stackrel{\Xi}{=}}$ & 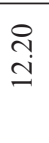 & 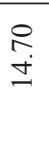 & $\begin{array}{l}n \\
n \\
0\end{array}$ & 宅 & 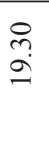 & $\begin{array}{l}\text { \&े } \\
\text { aे }\end{array}$ & $\begin{array}{l}\stackrel{+}{+} \\
\stackrel{\sim}{~}\end{array}$ & $\begin{array}{l}\text { बे } \\
\text { సे }\end{array}$ \\
\hline & 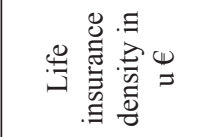 & $\hat{i}$ & $\vec{\vartheta}$ & $\stackrel{n}{\infty}$ & $\stackrel{\text { ํ. }}{\text { ă }}$ & $\stackrel{\Xi}{\Xi}$ & $\stackrel{\Xi}{g}$ & $\begin{array}{l}\vec{b} \\
\ddot{2}\end{array}$ & $\begin{array}{l}\stackrel{\circ}{ \pm} \\
\stackrel{+}{ \pm}\end{array}$ & 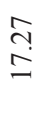 & $\begin{array}{l}\mathscr{a} \\
\infty \\
-\end{array}$ & 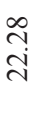 \\
\hline & 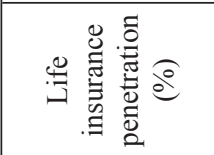 & $\stackrel{\infty}{\stackrel{\infty}{0}}$ & तె & $\tilde{\widetilde{o}}$ & $\overrightarrow{\tilde{o}}$ & ָิ & 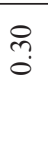 & సે & $\stackrel{m}{0}$ & $\begin{array}{l}0 \\
\stackrel{?}{0}\end{array}$ & $\vec{J}$ & $\stackrel{\infty}{+}$ \\
\hline & 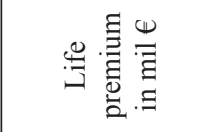 & $\begin{array}{l}\hat{n} \\
\infty \\
\infty \\
m\end{array}$ & $\frac{\hat{\sigma}}{\dot{\gamma}}$ & 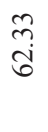 & $\frac{\vec{\sigma}}{\vec{r}}$ & $\begin{array}{l}\infty \\
\infty \\
\infty\end{array}$ & $\frac{\infty}{\stackrel{\infty}{\circ}}$ & $\begin{array}{l}\widetilde{O} \\
\infty \\
\infty\end{array}$ & 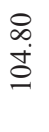 & $\begin{array}{l}\stackrel{\sim}{\sim} \\
\stackrel{\sim}{\sim}\end{array}$ & 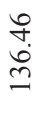 & $\begin{array}{l}\infty \\
\text { ñ. } \\
\stackrel{8}{0}\end{array}$ \\
\hline \multirow{4}{*}{ 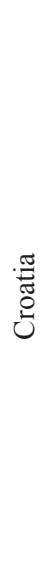 } & 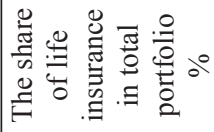 & $\begin{array}{l}\triangleright \\
\infty \\
\ddot{\sim}\end{array}$ & 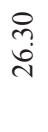 & $\begin{array}{c}\stackrel{\ominus}{N} \\
\stackrel{N}{N}\end{array}$ & 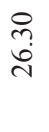 & $\begin{array}{l}\stackrel{+}{+} \\
\stackrel{\leftrightarrow}{\sim}\end{array}$ & $\begin{array}{l}\stackrel{8}{0} \\
\stackrel{0}{0}\end{array}$ & $\begin{array}{l}\stackrel{8}{0} \\
\stackrel{\leftrightarrow}{0}\end{array}$ & 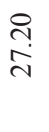 & $\begin{array}{l}8 \\
\text { \& } \\
\stackrel{\infty}{\sim}\end{array}$ & $\begin{array}{l}\stackrel{0}{ } \\
\infty \\
\stackrel{ల}{0}\end{array}$ & $\begin{array}{l}\hat{\sigma} \\
\dot{m}\end{array}$ \\
\hline & 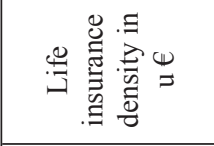 & $\begin{array}{l}\vec{\forall} \\
i \\
i\end{array}$ & $\frac{\hat{N}}{\sigma}$ & 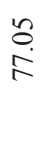 & $\begin{array}{l}\underset{\sigma}{\sigma} \\
\stackrel{\infty}{\infty}\end{array}$ & 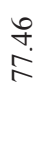 & $\begin{array}{l}\infty \\
\dot{b} \\
\dot{n}\end{array}$ & $\begin{array}{l}\stackrel{\infty}{\infty} \\
\stackrel{0}{\circ}\end{array}$ & $\begin{array}{l}n \\
\stackrel{n}{n}\end{array}$ & $\begin{array}{l}\tilde{\imath} \\
\stackrel{2}{2}\end{array}$ & 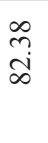 & $\frac{8}{\dot{a}}$ \\
\hline & 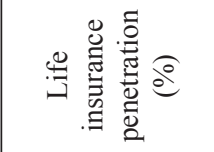 & $\stackrel{?}{\stackrel{0}{0}}$ & $\stackrel{m}{0}$ & $\hat{\imath}$ & $\stackrel{\mathbb{Z}}{\stackrel{0}{0}}$ & $\stackrel{n}{\stackrel{0}{0}}$ & $\stackrel{+}{\stackrel{0}{0}}$ & $\stackrel{N}{\stackrel{0}{0}}$ & $\stackrel{+}{\stackrel{0}{0}}$ & $\stackrel{\infty}{\stackrel{\infty}{0}}$ & $\begin{array}{l}\infty \\
\infty \\
0\end{array}$ & $\begin{array}{l}\infty \\
\infty \\
0 \\
0\end{array}$ \\
\hline & 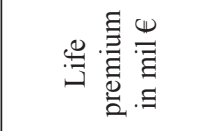 & 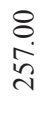 & $\begin{array}{l}8 \\
\stackrel{0}{\circ} \\
\stackrel{े}{ }\end{array}$ & $\begin{array}{l}8 \\
\text { ले } \\
\text { ले }\end{array}$ & $\begin{array}{l}8 \\
\dot{0} \\
\text { Lे }\end{array}$ & 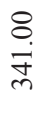 & $\begin{array}{l}\stackrel{8}{\text { m}} \\
\text { }\end{array}$ & $\begin{array}{l}\stackrel{8}{0} \\
\underset{\sim}{n}\end{array}$ & $\begin{array}{l}8 \\
\ddot{0} \\
\text { N }\end{array}$ & $\begin{array}{l}\stackrel{8}{0} \\
\text { } \\
\text { }\end{array}$ & 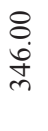 & 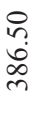 \\
\hline \multirow{4}{*}{ 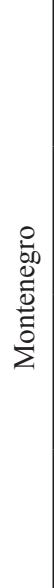 } & 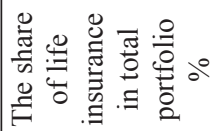 & $\begin{array}{l}\stackrel{8}{0} \\
\text { i }\end{array}$ & $\begin{array}{l}\widetilde{\sigma} \\
\dot{\sim}\end{array}$ & $\stackrel{\infty}{n}$ & $\stackrel{\circ}{\Xi}$ & 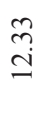 & $\begin{array}{l}\stackrel{\vartheta}{+} \\
\stackrel{2}{2}\end{array}$ & $\begin{array}{l}8 \\
\stackrel{ \pm}{ \pm}\end{array}$ & $\stackrel{\beth}{\underset{ \pm}{\Xi}}$ & $\begin{array}{l}\dot{S} \\
\dot{J}\end{array}$ & $\stackrel{\stackrel{m}{n}}{=}$ & $\stackrel{\infty}{\stackrel{0}{\sigma}}$ \\
\hline & 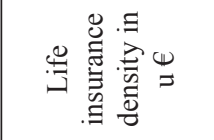 & กี & $\stackrel{\check{a}}{\sim}$ & ñ & $\begin{array}{l}\stackrel{\infty}{\circ} \\
\stackrel{\Xi}{=}\end{array}$ & $\begin{array}{l}\hat{\infty} \\
\stackrel{\sim}{二}\end{array}$ & $\begin{array}{l}\infty \\
\stackrel{m}{\sim} \\
\stackrel{n}{n}\end{array}$ & $\begin{array}{l}\infty \\
\stackrel{\infty}{ \pm}\end{array}$ & $\begin{array}{l}\infty \\
i \\
i \\
\end{array}$ & $\stackrel{+}{\stackrel{+}{c}}$ & 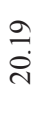 & $\begin{array}{l}\infty \\
\stackrel{\infty}{\circ} \\
\stackrel{\sim}{0}\end{array}$ \\
\hline & 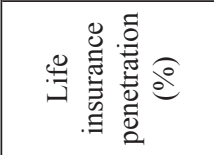 & $\stackrel{n}{0}$ & $\stackrel{\infty}{\circ}$ & $\overrightarrow{\tilde{o}}$ & $\underset{\text { ஸे }}{0}$ & ઼ָ & તิ & ઼ָ & ते & $\stackrel{m}{0}$ & $\hat{n}$ & 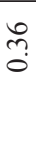 \\
\hline & 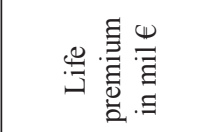 & $\begin{array}{c}\stackrel{\infty}{\infty} \\
0 \\
0\end{array}$ & $\stackrel{\infty}{\infty}$ & $\vec{\sigma}$ & 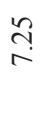 & $\underset{\infty}{\stackrel{\infty}{\infty}}$ & $\hat{m}$ & $\stackrel{2}{\circ}$ & チ̊. & $\begin{array}{l}\hat{\infty} \\
\stackrel{0}{0}\end{array}$ & $\begin{array}{l}\stackrel{n}{a} \\
\end{array}$ & 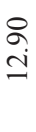 \\
\hline 兽 & 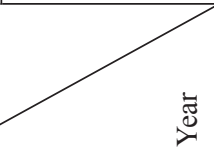 & 苂 & ஜ̊ & ڤ్̀े & $\stackrel{\infty}{\stackrel{\infty}{\circ}}$ & ஓे & $\stackrel{\circ}{\stackrel{\sim}{\sim}}$ & $\overrightarrow{\vec{d}}$ & 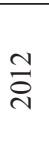 & $\stackrel{m}{\stackrel{n}{d}}$ & $\underset{\sim}{\stackrel{\Delta}{\sim}}$ & $\frac{n}{\stackrel{n}{r}}$ \\
\hline
\end{tabular}


Milijana Novović Burić et al. • Impact of economic factors on life insurance development... Zb. rad. Ekon. fak. Rij. $2017 \cdot$ vol. $35 \cdot$ no. $2 \cdot 331-352$

\begin{tabular}{|c|c|c|c|c|c|c|c|c|c|c|c|c|}
\hline 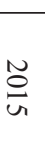 & $\begin{array}{l}\tilde{N} \\
\stackrel{0}{\perp}\end{array}$ & $\underset{\omega}{\stackrel{N}{c}}$ & $\stackrel{N}{\stackrel{N}{N}}$ & $\stackrel{N}{\varrho}$ & $\frac{N}{O}$ & 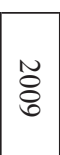 & 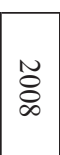 & 芯 & $\begin{array}{l}\tilde{o} \\
\text { ă }\end{array}$ & $\begin{array}{l}\tilde{n} \\
\tilde{8} \\
u\end{array}$ & 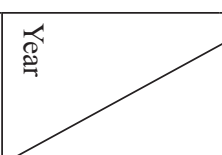 & 音 \\
\hline$\stackrel{\vec{u}}{\vec{u}}$ & $\begin{array}{l}u \\
\infty \\
w \\
\perp\end{array}$ & $\stackrel{u}{0}$ & $\begin{array}{l}+ \\
\dot{d} \\
\dot{u}\end{array}$ & $\begin{array}{l}\overrightarrow{0} \\
\dot{0} \\
心\end{array}$ & $\begin{array}{l}\omega \\
\infty \\
=\end{array}$ & $\begin{array}{l}w_{n} \\
\ddot{o}\end{array}$ & $\begin{array}{l}\underset{\omega}{\omega} \\
\sqcup\end{array}$ & 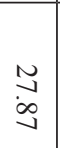 & $\begin{array}{l}\tilde{O} \\
\stackrel{0}{1} \\
\text { N }\end{array}$ & $\overrightarrow{\dot{w}_{\omega}}$ & 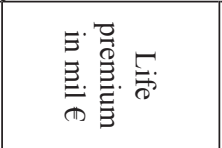 & \\
\hline$\stackrel{\circ}{\perp}$ & $\begin{array}{l}\stackrel{0}{ \pm} \\
\end{array}$ & $\begin{array}{l}\dot{i} \\
\infty \\
\infty\end{array}$ & $\begin{array}{l}\dot{i} \\
\omega \\
\end{array}$ & $\underset{\dot{\omega}}{i}$ & iu & i & i & $\begin{array}{l}\dot{\sim} \\
\text { un }\end{array}$ & $\stackrel{i}{\sim}$ & $\stackrel{0}{6}$ & 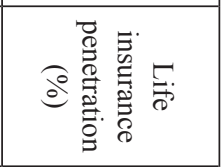 & 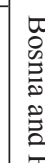 \\
\hline $\begin{array}{l}\vec{\infty} \\
\dot{\phi}\end{array}$ & $\begin{array}{l}\vec{a} \\
\dot{\omega}\end{array}$ & $\vec{F}$ & $\begin{array}{l}0 \\
\dot{0} \\
\end{array}$ & $\stackrel{0}{0}$ & $\begin{array}{l}\infty \\
\stackrel{ \pm}{ \pm}\end{array}$ & $\begin{array}{l}\vec{\infty} \\
\dot{\infty}\end{array}$ & $\begin{array}{l}\vec{A} \\
\vec{b}\end{array}$ & $\dot{\vec{b}}$ & $\begin{array}{l}\overrightarrow{i n} \\
\dot{\perp}\end{array}$ & $\begin{array}{l}\omega \\
\dot{\omega}\end{array}$ & 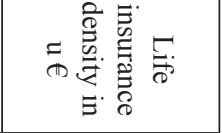 & 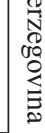 \\
\hline$\stackrel{\sim}{\circ}$ & $\begin{array}{l}n \\
\stackrel{8}{8} \\
\dot{8}\end{array}$ & $\begin{array}{l}\infty \\
\dot{\delta}\end{array}$ & $\overrightarrow{\vec{u}}$ & $\begin{array}{l}\vec{a} \\
\vec{b}\end{array}$ & $\begin{array}{l}\vec{u} \\
\vec{\sigma}\end{array}$ & $\begin{array}{l}\vec{u} \\
\dot{I}\end{array}$ & $\vec{F}$ & $\begin{array}{l}\vec{w} \\
\dot{u}_{u}\end{array}$ & $\underset{\dot{\infty}}{\vec{\phi}}$ & $\begin{array}{l}0 \\
\dot{u}\end{array}$ & 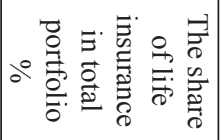 & \\
\hline $\overrightarrow{\breve{~}}$ & $\underset{+}{\overrightarrow{+}}$ & 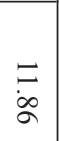 & $\begin{array}{l}\dot{\stackrel{\omega}{\omega}} \\
\dot{\omega}\end{array}$ & $\begin{array}{l}\infty \\
\dot{\infty}\end{array}$ & $\begin{array}{l}u \\
\ddot{\alpha}\end{array}$ & $\vec{i}$ & $\begin{array}{l}\vec{\omega} \\
+\end{array}$ & $\begin{array}{l}\stackrel{\sim}{\ddot{\infty}} \\
\dot{\infty}\end{array}$ & $\begin{array}{l}\vec{\infty} \\
\infty \\
\infty\end{array}$ & $\overrightarrow{\dot{\infty}}$ & 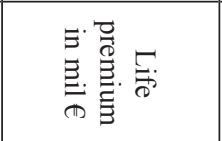 & \\
\hline 莕 & $\stackrel{\circ}{\Xi}$ & $\stackrel{0}{\dot{u}}$ & $\stackrel{\circ}{\dot{\omega}}$ & $\stackrel{\circ}{\doteq}$ & $\begin{array}{l}\dot{0} \\
\dot{\infty}\end{array}$ & $\stackrel{\dot{0}}{\dot{0}}$ & $\dot{\circ}$ & 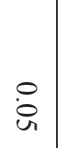 & 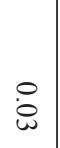 & $\stackrel{8}{\dot{1}}$ & 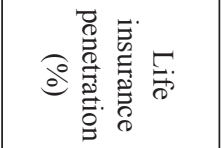 & 这 \\
\hline $\begin{array}{l}\infty \\
\dot{u}\end{array}$ & $\begin{array}{l}\infty \\
\infty \\
\infty\end{array}$ & $\begin{array}{l}u \\
\dot{a}\end{array}$ & $\stackrel{+}{\dot{\sigma}}$ & $\begin{array}{l}w \\
\dot{\infty} \\
w\end{array}$ & $\begin{array}{l}\omega \\
\dot{\theta}\end{array}$ & $\begin{array}{l}n \\
+ \\
a\end{array}$ & $\stackrel{N}{\Xi}$ & $\bar{\omega}_{\sigma}$ & $\begin{array}{l}\stackrel{0}{\circ} \\
+\end{array}$ & $\begin{array}{l}\dot{0} \\
\dot{0}\end{array}$ & 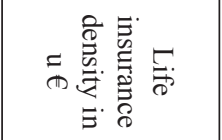 & కి \\
\hline 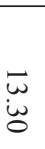 & $\begin{array}{l}\bar{N} \\
\dot{8}\end{array}$ & $\begin{array}{l}\dot{\circ} \\
\dot{8}\end{array}$ & $\begin{array}{l}\infty \\
\vdots \\
\omega\end{array}$ & $\overrightarrow{\overrightarrow{ \pm}}$ & $\begin{array}{l}u \\
\pm\end{array}$ & $\underset{\dot{\infty}}{\infty}$ & $\stackrel{\vec{\omega}}{\dot{\omega}}$ & $\begin{array}{l}\stackrel{n}{\infty} \\
\dot{o}\end{array}$ & $\begin{array}{l}N \\
\dot{0}\end{array}$ & $\begin{array}{l}N \\
\vdots \\
0\end{array}$ & 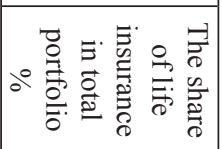 & \\
\hline 岕 & $\dot{u}_{\omega}$ & $\stackrel{\infty}{\infty}$ & $\underset{\omega}{\dot{\omega}}$ & $\vec{a}$ & $\stackrel{\partial}{\dot{u}}$ & $\begin{array}{l}u \\
\dot{b} \\
\infty\end{array}$ & $\stackrel{\vec{i}}{\underline{U}}$ & $\stackrel{w}{\omega}_{\omega}^{w}$ & $\begin{array}{l}\tilde{n} \\
\ddot{\alpha}\end{array}$ & $\stackrel{n}{8}$ & 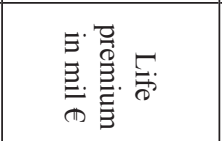 & \\
\hline ஜ̊ & $\stackrel{\dot{\theta}}{\dot{\theta}}$ & $\stackrel{\dot{\theta}}{\dot{\theta}}$ & $\dot{\dot{v}}$ & $\dot{\infty}$ & $\dot{\dot{v}}$ & $\dot{2}$ & $\dot{\ddot{\theta}}$ & $\stackrel{\circ}{\not}$ & $\stackrel{\circ}{\dot{w}}$ & $\stackrel{8}{\dot{\omega}}$ & 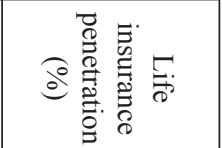 & $\geq$ \\
\hline $\begin{array}{l}\stackrel{N}{\omega_{1}} \\
\infty\end{array}$ & $\mid \begin{array}{l}n \\
\tilde{\omega} \\
\end{array}$ & $\begin{array}{l}N \\
\dot{w} \\
\sim\end{array}$ & 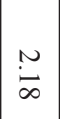 & $\begin{array}{l}n \\
\dot{N}\end{array}$ & $\stackrel{N}{=}$ & $\dot{\infty}$ & $\overrightarrow{\dot{\omega}}$ & $\dot{\vec{n}}$ & $\stackrel{\circ}{\infty}$ & $\dot{v}$ & 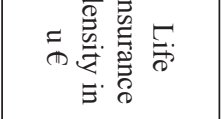 & \\
\hline iे & $\begin{array}{l}\infty \\
\infty \\
\infty\end{array}$ & $\overrightarrow{\mathcal{u}_{u}}$ & $\begin{array}{l}0 \\
\infty \\
\perp\end{array}$ & $\underset{\sim}{\vec{N}}$ & $\begin{array}{l}\overrightarrow{\dot{\omega}} \\
+\end{array}$ & $\frac{0}{6}$ & $\overrightarrow{\dot{\omega}}$ & $\dot{\ddot{\theta}}$ & $\dot{\vec{y}}$ & $\begin{array}{l}u \\
\dot{b} \\
u\end{array}$ & 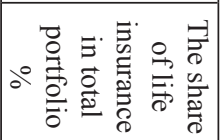 & \\
\hline
\end{tabular}

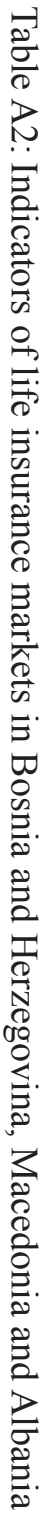

